\title{
携帶型硝子電極 $\mathrm{pH}$ メーターに就いて
}

\author{
Portable Glass Electrode $\mathrm{pH}$ Meter
}

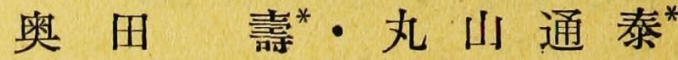 \\ Hisashi Okuda \\ Michiyasu Maruyama}

\section{1. 緒 言}

化學工業に於て $\mathrm{pH}$ を正確且つ簡易に測定を行らこと は極めて重要な事柄である。從來一般實驗室及び現場等 にて之が測定にはアンチモン電極法,比色法, $\mathrm{pH}$ 試驗紙 法等が用いられて來たが，夫等は何れる精度並びに適用 範園等の點にて種々な缺陷があつた。一方研究室にては 水素ガス電極法が用いられる外, 硝子電極法の侀究が行 われ 1930 年に至り FP-54 の如き電位計管の出現と共 に $\mathrm{pH} の$ 測定は極めて精密に行える樣になつた。こつに 硝子電極法が他の測定法に比べてすぐれていると考えら れる諸點を簡單に記してみると, $\mathrm{i}$ )水溶液にて $\mathrm{pH} 0 \sim 12$ の範園にて簡單且つ正確に測定出來る。ii) 起電力の平 衡に達する時間が極めて短い。從つて變化し易い物質の pH を迅速に測定するに適する。iii) 酸化還元性物質に よる影響を受けない。iv) 被檢液の着色, 混溜，流動性 等に無關係に又宾氣其他のガスの存在下に於ても使用出 來ること等である。然るに硝子電極法の優秀性が認めら れ乍ら我國にて一般に普及されていない狀態にあるその 原因として考える處は硝子膜の電氯抵抗が大きいため通 常の電位差計，檢流計の組合せにては測定困難なための 椂である。而して之が測定には從來扸究室で用いて來た

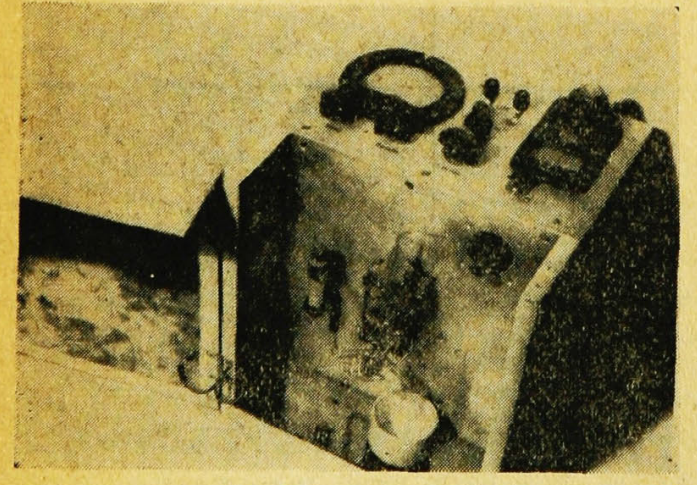

第 1 圖

*三井化學工業株式會社目黑砸究龍
FP-54による裝置があり最も精密な測定結果が得られる のであるが數多くの附屬品を必要とし且つ夫等は何れる 高價であり一般向でない。從つて小型輕量にして操作容 易且つ安價な硝子電極 $\mathrm{pH}$ メーターを得んと考えて $1 \mathrm{~A} 7$ GTを用いる回路で試作した處幸に所期目的を達成した のでこつに赭告する。

\section{2. 測 定 方 式}

簡易型裝置として交流方式と乾電池式の二方法が考え られる。交流方式を檢討してみると必要精度を保持させ るためには電源の安定化に經費を要し又小型輕量といら 目的にも合致しない。從つて交流式を用いるのは此場合 不適當と判斷した。後者の乾電池式は電池の消耗による 交換を必要とする不利はむるが交流電源のない場所にで も撨行使用出來，比較的簡單に實用的精度が得られるの で本方式によることつした。

\section{3. 裝 置 概 要}

第 1 圖に本裝置の外䧳を，第 2 圖にその配線圖を示し た。裝置は硝子電極による測定部，自空管電壓計部，電 位差計部の三部分からなり電源を含めて一切を静電遮蔽 を行つた約 $20 \mathrm{~cm}$ 立方の箱に收めた。な挌各構成部の所 要品の選擇に當つて測定精度 $0.1 \mathrm{pH}$ を維持するに止め た。

\section{(i) 眞空管電壓計棓}

製作に當つこ最も大切なことは值空管の選擇と回路の

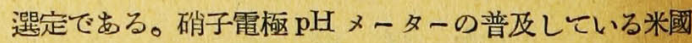

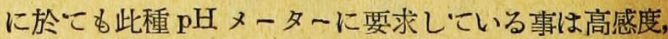
高精度ではなくて主として安定性，堅牢性にむる樣であ る。從つて餘り良質と言えない、電氯部品を使用する我國 の現狀にて感度の向上を求めて壖幅段數を㙘加すること は却つてそれだけ安定度の低下と消費電力の堙大を件い 必ずしも有利ではない。上述の理由から本裝置にては第 2 圖の如き單球式回路を採用したが，幸に最も簡單な檢 流計 $\left(7 \times 10^{-7} \mathrm{~A}\right.$ 指針型) を用いて電位差 $1 \mathrm{mV}$ が澰知 せられ感度の不足を認めなかつた。次に $1 \mathrm{A7GT}$ 選擇の 

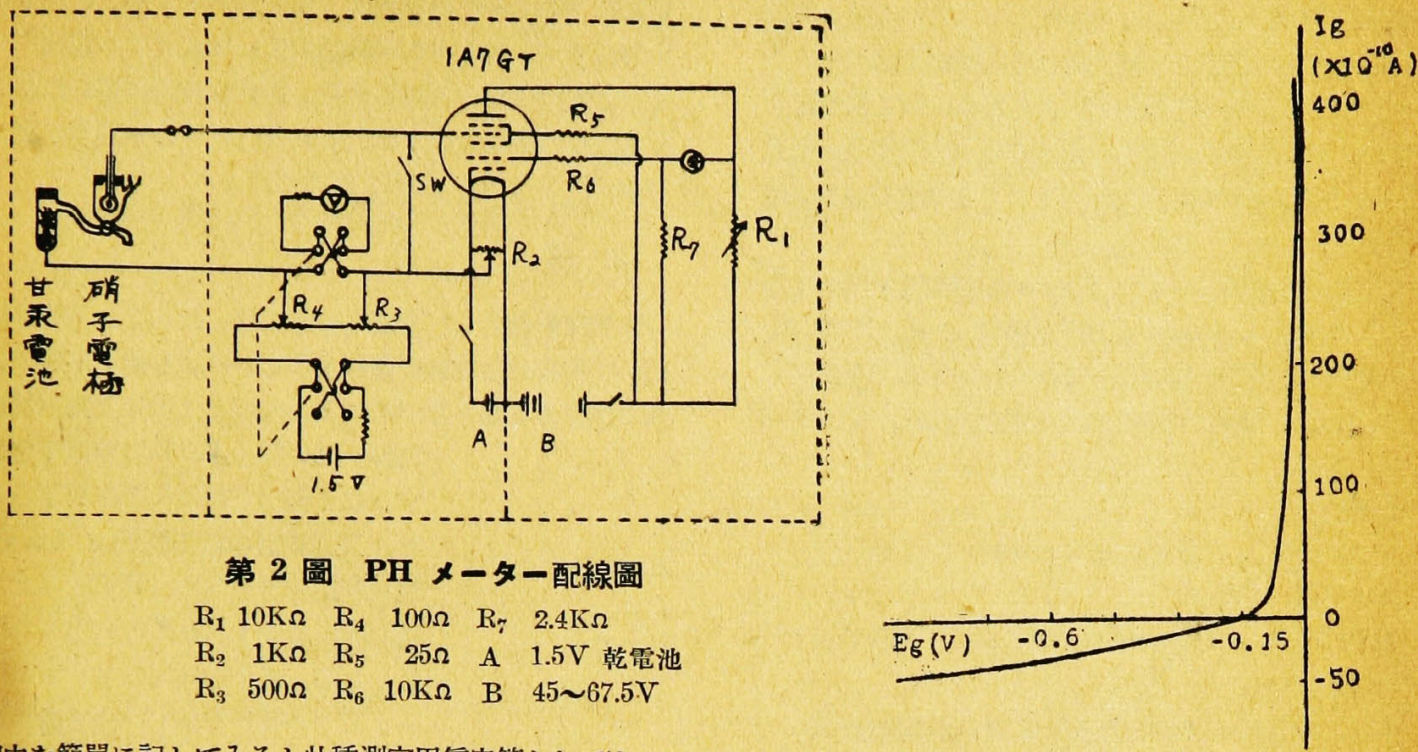

理由を簡單に記してみると此種測定用眞空管としては, FP-54の如く格子電流が可及的小さく且つ入力抵抗の高

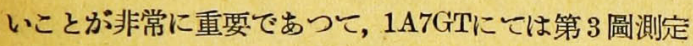
結果に見る如く格子電流を非常に小さくすることが出來 又その構造からみと入力抵抗も相當に高く受信管中にて 最も適當なるのと考えた。及 54 に比して相互コンダク タンスる可成り大きく第 2 圖の如き平衡回路を用いる時 陽極及び發振格子は制御格子に對し夫々正及び負の相互 コンダクタンスを有するので出力に於て 2 倍の相互 マン ダクタンスを有するのと同等となり檢流計す低感度のす のにて沿まし得る利點がある。な捎費電力も $\mathrm{Ef} 1.4 \mathrm{~V}$, If 50ma にて極めて少ない。

\section{(ii) 電位差計部}

本裝置に要求される精度が $0.05 \sim 0.1 \mathrm{pH}$ (E. M.F.に して 3〜 6mV) であるのでフル・スケール $500 \mathrm{mV}$ の電 堅計と 2 個の可變抵抗を組合せた簡單なるので目的を達 し得た。精密測定にはダイャル式(マンガニン線卷抵抗) の電位差計を使用すべきであるか゚それに件つて標潐電池 による較正を要する等, 裝置及び操作を袙雜化するのみ にて其必要を認めなかつた。なおメーターによる場合讀 取りの小さくなる缺點があるので, 電位差計は正負轉換 出來る如くしスケール目盛の擴大を計る外, 正・負 $\mathrm{E}$.

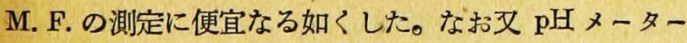
の場合，目盛は $\mathrm{pH}$ 直望とすることが望ましいが見在の 國產硝子電極にては其の起電力の經時的變化る考慮に入 れなければならず，又破損時互換性のある電極を簡單に 得られない、等の理由から $\mathrm{pH}$ 目盛を刻むことは困難であ

\section{第 3 圖 $\mathbf{E g}-\mathbf{I g}$ 特性}

る。同樣の理由から E.M. F.に溫度補償を入れる事る省 略し, 多少不便ではむるが $\mathrm{mV}$ 讀取りとして必要な補 正は計算にて加える事とした。

(iii) 硝子電極部

硝子電極は何處にても簡單に作製補充出來る如く並ガ ラスにーハーバー型電極とし,內部には $0.1 \mathrm{~N} \mathrm{HOl} \mathrm{にキ}$ ンヒドロンを飽和せしめ白金電極を挿入した。又硝子球 は破損し易く被检夜の交換に注意と手數を要するので, 第 1 圖の如きモルトン型の保持器に收容し, 操作の容易 と測定の迅速化を計つた。な打硝子電極の如き高抵抗回 路に於ては格子導線の絕緣を高度に保ち且つ外部よりの 電氣誘導を防ぐことが極めて重要なことである。濕潤期 に硝子電極の測定が困難と言われるのは主として此部の 表面漏洩による絕緣低下であるので本裝置にては特に此 點に留意し，格子導線の支持は引出部一個所のみとし且 つ表面抵抗の高いマイカ板にて引出空を作り之にエボナ イト製のプッシングを付して引出端子とした處，裝置全 體の完全なる埥電遮蔽と相俟つて梅雨期にてり何等支障 なく安定なる測定を行らことが出來た。

\section{4. 測定操作及び實驗結果}

測定前の調整としては先づ $\mathrm{R}_{1}$ を調節して檢流計の指 針を零點に持來し，序で格子スイッチ $\mathrm{SW}$ を閉じて $\mathrm{R}_{2}$ により同じく指針を零點に持隶す。此の操作により第 3 圖の如く本裝置にては略ぼ $\mathrm{Eg}-0.15 \mathrm{~V}$ 附近にて格子電流 が最小となつた。被檢液の測定には電極よりの導線を格 
子引出端子に結び， $\mathrm{R}_{3}, \mathrm{R}_{\mathbf{4}}$ を調整して以て被檢液と電位. 善計の起電力を補償して檢流計Gの零點が變動しないこ そを格子スイッチ SWの開閉により確めたのち電堅計を 㰓取る。更に同樣の測定を一或は二の $\mathrm{pH}$ 既知の緩鿉液 について行い簡單な計算又はグラフより被检液の $\mathrm{pH}$ 值 を求める。

本裝置の較正實驗として Sörensen 緩衝液を用いて並 ガラス電極と Beckman \# 290 電極にて pH-E. M. F. 特性を調べた處第 4 圖の如く Mac Innes 硝子を使用し た Beckman 電極は非常に優秀な特性を示し, 並ガラス

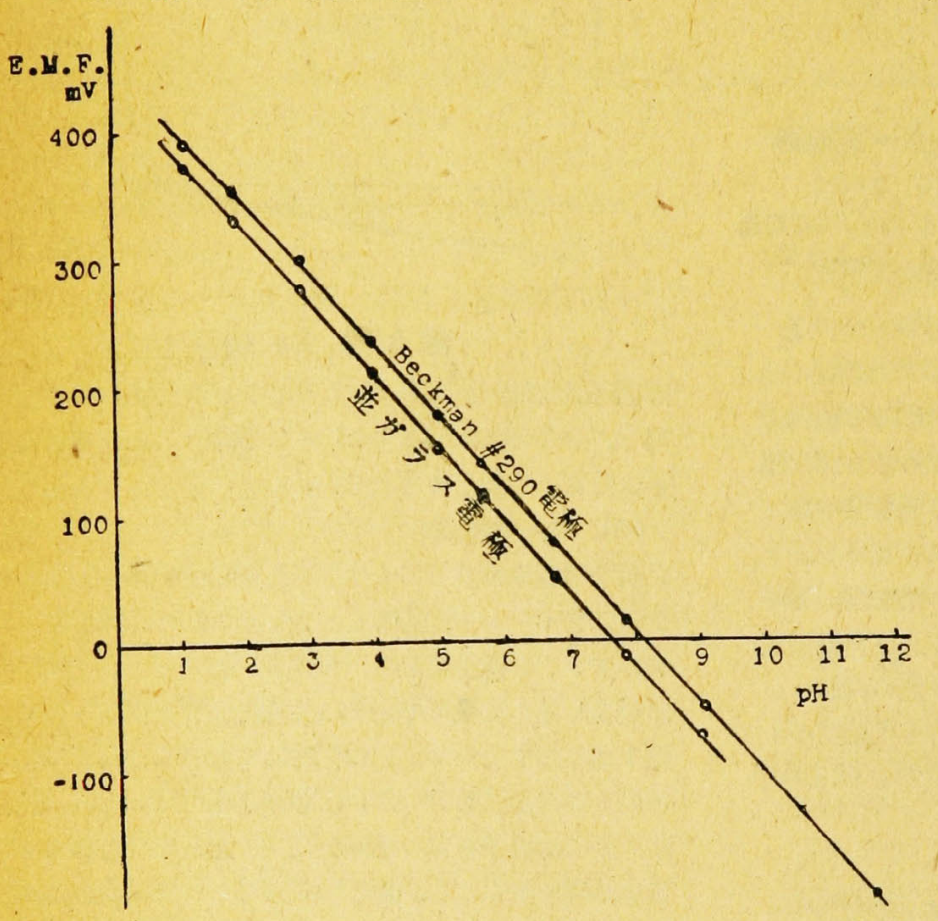

第 4 圖 pH-E. M. F. 特性
電極は $\mathrm{pH}$ 1〜9 の範圍にて值線性を示すがそれ以上に て型曲する。作し乍ら一般的用途には並ガラス電極にて あ十分實用になると思われる。な打本測定に用いた並力゙ ラス電極の起電力は $1 \mathrm{pH}$ 當り $58.1 \mathrm{mV}$ の理論値に對し $55.4 \mathrm{mV}$ となりた ( $20^{\circ} \mathrm{O}$ に於て)。

\section{4. 結言}

本裝置を綜合して考察して見る時, 要求される精度に 基いて所要品を適當に選擇せることにより構造が簡單に なり操作も容易となつたこと，並ガラスの如き高抵抗の

電極を用いてる E.M.F.の低下を來 すとなく測定し得る機能を有するこ と, 又電厣計の較正誤差士 $1 \mathrm{mV}$ 讀取り誤差等を含めて誤差は $3 \mathrm{mV}$ 範園內にあり $0.05 \mathrm{pH}$ の精度を有す

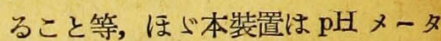
ーとしての條件を滿し一般實驗室現 場用として十分實用性むるものと思 われる。

擱筆に當り本實驗に對し種々御配 虑御指導を賜つた三井化學工業株式 會社目黑矿究所安田所長に對し深? 謝意を表する。

(昭和 26 年 8 月 6 日受理)

$$
\text { 文献 }
$$

(1) D. B. Penick, Rer. Sci. Instruments. 6, 115 (1935)

(2) Garman \& Droz, Ind. Eng. Chem. Anal. Ed., 398 (1939)

(3) M. Dole, "The Glass Electrode" (1947)

\section{ポリ監化ビニル樹脂中の可塑劑の分析 盟化ビ =} 几試料をりゥクスレー抽出器で $6 \mathrm{hr}$. エーテル抽出し, 溶劑を除いた可塑劑についてナトリウムと熔融して $\mathrm{N}$, $\mathrm{Cl}, \mathrm{S}, \mathrm{P}$ の定性分析を行い，次にレン゙ルシンヌびフェ， ールと加熱してフタレートの存在を見，更にフェノール 類成分を 2,6-ジブロムキノリン・クロルイミドのインド フェノール是色で調へる。定量分析は襖化價, 屈折率を はかり, 鹼化して生じたフタール酸カリの沈澱からフタ レートの量を求め, スリンの含量からホスフェートを求
める。更にエステル型の可塑劑は $\mathrm{KOH}$ とエチレングリ コール中で加水分解し,溜出したアルコール成分を沸點; 屈折率で確認寸る。以上の化學分析の結果と赤外線吸收 スペクトルとから確定する。赤外線吸收は混合したもの では必ずしも充分な結果が得られないが，フタレート， ホスフェート, 脂肪酸, エステル基, 芳香族等の特有吸 收とから分析が可能である。(J. Haslam 他，J. Appl. Chem, 1, 112 (1951)) (山下雄也) 